\title{
NARRATIIVI AEG JA TÕLKE AEG: DISKURSIIVNE KÄSITLUS
}

\author{
Triin Lõbus, Silvi Tenjes
}

\begin{abstract}
Ülevaade. Kognitiivses narratoloogias mõistetakse ilukirjandusliku narratiivi interpreteerimist lugeja poolt kui loomaailmast mentaalsete representatsioonide konstrueerimist tekstis leiduvate keeleliste markerite põhjal. Käesolevas artiklis uuritakse aspektikategooria rolli selles protsessis, võrreldes hispaaniakeelseid narratiive nende eestikeelsete tõlgetega. Lähtutakse sotsiokognitiivsest käsitlusest, mille kohaselt kirjanduslikku narratiivi vaadeldakse sotsiokultuurilise praktikana, mis eeldab teatud konventsioonide järgimist tähenduse loomisel. Analüüsitakse nn narratiivse imperfekti rolli narratiivi ajalise mõõtme kujundamisel ning samuti ruumi ja eelkõige vaatepunkti konstrueerimisel hispaania keeles ning käsitletakse võimalusi samasuguste modifikatsioonide väljendamiseks eestikeelses tõlkes.*
\end{abstract}

Võtmesõnad: diskursusanalüüs, tekstianalüüs, narratoloogia, grammatiline aeg, aspekt, eesti keel, hispaania keel

\section{Sissejuhatus}

Käesolevas artiklis uurime ajakäsitlusi ilukirjanduslikus narratiivis hispaaniakeelse originaali ja eestikeelse tõlke võrdluses. Analüüsime nn narratiivse imperfekti ${ }^{1}$ rolli hispaania keele jutustamistehnilise ja stilistilise vahendina ning probleeme ja võimalusi kõnealuse vormi edasiandmisel eesti keeles nii, et tõlke lugeja võiks tekstis kodeeritud loomaailma kogeda võimalikult samal viisil kui autor on selle konstrueerinud hispaania keeles. Narratiivseks imperfektiks nimetatakse romaani keeltes narratiivses diskursuses esinevat eripärast aspektikasutust, mille puhul imperfektiivset verbivormi kasutatakse selliste sündmuste kujutamiseks, mille ajalis-aspektiline iseloom eeldaks perfektiivset aspekti.

Laiemas mõttes käsitleb meie analüus küsimust, missuguseid aja kategoriseerimise põhimõtteid rakendavad inimesed oma intuitiivses maailmanägemises ja

\footnotetext{
* Artikkel on valminud Eesti Teadusfondi grandi nr 8008 toel. Autorid tänavad kaht anonüümset retsensenti väärtusliku tagasiside eest.

1 Erinevalt eesti grammatikatraditsioonist, kus terminit imperfekt kasutatakse üldise lihtmineviku tähenduses, mõistame käesolevas artiklis selle all hispaania keele imperfektiivse aspektitähendusega minevikuvormi.
} 
kui palju sellest annab ette konkreetne keel. Aeg ja ruum on maailma eksistentsi määravad parameetrid ja inimliku kogemuse põhivormid. Inimene juhindub oma teadvuses ja tegevuses ühtedest või teistest maailmapildi põhikategooriatest, mis on kätketud keelde, ja mõelda maailmast nende kategooriateta on niisama võimatu nagu mõelda väljaspool keele kategooriaid (Gurevitš 1992). Kui kirjandusteksti autor on kategoriseerinud teatud seotud sündmusi keeleliste kategooriate vahendusel, võib valikut käsitleda kategoriseerimisaktina, mis näitab keelekasutaja mõtlemisteid.

Narratiivi mõistmine tekstis leiduvate keeleliste markerite ja nende põhjal tehtavate järelduste abil on üheks peamiseks uurimisobjektiks nn kognitiivses narratoloogias, kus seda protsessi käsitletakse kui loomaailma (re)konstrueerimist. See tähendab, et narratiivi interpreteerimise käigus lugeja loob ja aktualiseerib mentaalseid mudeleid maailmast, millest loos räägitakse. Loomaailma võibki vaadelda kui globaalset mentaalset representatsiooni sellest, kes tegi mida kellele, millal, kus, miks ja mil viisil. (Herman 2000, 2002)

Hispaania ja eesti keele võrdlus on huvipakkuv sellepärast, et hispaaniakeelse narratiivi autor kategoriseerib sündmusi reeglipäraselt grammatilise aspektikategooria vahendusel, mis eesti keele ajakogemuses samal viisil ei kajastu, kuid mis mängib olulist rolli narratiivi ajalise struktuuri väljendamisel ja interpreteerimisel. Oma analüüsis vaatlemegi narratiivse imperfekti rolli loomaailma ajastruktuuri konstrueerimisel. Samuti pöörame tähelepanu ajastruktuuri seostele ruumisuhete ja narratiivi vaatepunktiga, kust loomaailma sündmusi implitsiitselt nähakse, kogetakse, mõistetakse ja hinnatakse. Põhieristusena võib vaatepunkt asuda kas loomaailma sees või sellest väljaspool (Uspenskij 1970). Esimesel juhul on vaatepunkt omistatav mõnele tegelastest, kujutades loomaailma sündmusi tema subjektiivsest füüsilisest ja psühholoogilisest perspektiivist lähtuvalt. Teisel juhul luuakse objektiivne vaatepunkt, mis võib olla rohkem või vähem piiratud, nn kõiketeadvast jutustajast kuni kõrvalseisva vaatleja perspektiivini, kust esitatakse vaid kujuteldavas loomaailmas väliselt nähtavat.

Traditsiooniliselt on grammatilise aja ja ka aspekti käsitlemisel lähtutud Hans Reichenbachi (1947) analüüsist, kirjeldades kõnealuste vormide semantikat kõnehetke, sündmuse hetke ja viitehetke vaheliste suhete kaudu (Fleischman 1991, Comrie 1993). Eesti keele verbiaegu on uurinud eelkõige Helle Metslang (1994), kes lähtub samuti samast formalistlikust suunast ning piirdub oma käsitluses lihtlausega; eesti keele ajakasutust tekstis võrdluses soome keelega on käsitlenud Valma Yli-Vakkuri (1994). Erinevalt Reichenbachist lähtuvast traditsioonist on käesoleva analüüsi aluseks kognitiivne lähenemisviis, milles võetakse arvesse ka ilukirjandusliku narratiivi kui diskursuseliigi sotsiokultuurilisi aspekte. Meie käsitlus kognitsioonist ühtib Lenny Shedletsky definitsiooniga, mille järgi kognitsioon hõlmab 1) mitmesuguseid mentaalseid entiteete (ingl mental entities, eesti keeles ka meeles paiknevaid), nagu mõtted, tähendused, ideed, hoiakud, teadmised, uskumused, tajumused, kavatsused, mälestused, kujutluspildid, unistused, meeleseisundid, teadvus ja alateadvus, ning 2) mentaalseid operatsioone (the operations of the mind, eesti keeles ka meeles teostatavaid), nagu seostamine, infootsing, võrdlemine, tähelepanu ja järeldamine (Shedletsky 2008: 541). Käesolevas töös peetakse kognitiivse lähenemisviisi all silmas looja- ja lugejapoolset loomaailma konstrueerimist, narratiivi esitust ja interpreteerimist. 


\section{Aeg, aspekt ja narratiiv}

Mitmed uurijad (Bruner 1986, Talmy 1995, Herman 2000) on oletanud, et narratiiv üldises mõttes kui teatud mõtlemise strateegia on omaette kognitiivne süsteem, mis võimaldab meil kogemust struktureerida ja mõista. Narratiivse kognitiivse süsteemi funktsioon on seostada ja integreerida teadvussisu teatud komponendid läbi aja koherentseks struktuuriks (Talmy 1995: 422), muutes meie reaalsuskogemuse mõistetavaks ja manipuleeritavaks.

Olulisim narratiivi defineeriv omadus on just selle ajalisus. Narratiivi võib defineerida kui sündmuste järgnevuse järjestikuselt organiseeritud representatsiooni (Genette 1972, Chatman 1990). Käesoleva artikli uurimisteema seisukohalt on oluline, et ajaline järgnevus on lahutamatult seotud sündmuste aspektuaalse analüüsiga. Germaani ja romaani keelte ajasüsteemis ei ole aspektile pööratud nii palju tähelepanu kui grammatilisele ajale, sest eraldiseisev grammatiline aspektikategooria puudub. Hispaania keeles on verbi morfoloogias avalduvatesse ajatähendustesse kodeeritud nii olevik, minevik kui ka tulevik ning aspekt on grammatilise ajaga põimunud sel viisil, et minevikuvormides on samaaegselt väljendatud ka perfektiivsus või imperfektiivsus. Traditsioonilises grammatikas käsitletakse neid vorme ühtviisi verbiaegadena, kuid Joan L. Bybee ja Östen Dahl peavad aspektuaalset eristust peamiseks. Hispaania keele, nagu ka teiste romaani keelte ajalis-aspektuaalsed põhikategooriad moodustavad seega kolmiksüsteemi, kus 'minevikuline perfektiiv' on opositsioonis 'minevikulise imperfektiivi' ja 'mitteminevikulise imperfektiiviga' (mitte 'olevik' opositsioonis 'perfektiivse mineviku' ja 'imperfektiivse minevikuga') (Bybee, Dahl 1989: 85). Käesolevas analüüsis huvitabki meid perfektiivi-imperfektiivi eristus minevikuvormide vahel, sest need on peamised ilukirjanduslikus narratiivis kasutatavad vormid.

Imperfektiivsuse-perfektiivsuse opositsiooni semantikat kirjeldatakse enamasti kas piiritletuse-mittepiiritletuse või totaalsuse-partsiaalsuse kaudu. Viimast käsitlusviisi esindab ka Bernard Comrie (1995) paljutsiteeritud definitsioon, mille kohaselt perfektiivne aspekt kujutab sündmust ühtse tervikuna, eristamata seda moodustavaid erinevaid faase (totaalne kujutusviis), ja imperfektiivne aspekt viitab sündmuse sisemisele ajalisele struktuurile, seda vaadeldakse seestpoolt (partsiaalne kujutusviis). Nils B. Thelin (2002) omistab aspektuaalsele analüüsile keskse koha tajus ja kognitsioonis, mille aluseks on meid ümbritseva kaose osadeks jaotamine. See primaarne aspektuaalne analüüs seisnebki osa-terviku eristuses, mille abil eristame ja suhestame omavahel objekte ja sündmusi meid ümbritsevas kaoses. Suhteid objektide vahel mõistetakse kui suhteid ruumis ja muutused nendes suhetes on põhjustatud objektide liikumisest ruumis. Liikumist omakorda mõistetakse toimuvana ajas, kuna ruumis toimuvat muutust reinterpreteeritakse muutusena ühest olukorrast teise (vanast uude). Nii tekib algse sündmuste ajalis-ruumilise ehk aspektuaalse eristamise baasilt primaarne ajaline eristus enne-pärast. Seega sündmuste järjestamine eeldab nende aspektuaalset analüüsi, sest järjestamiseks tuleb need piiritleda alguse ja lõpuga, s.t vaadelda neid totaalselt. Sellega kooskõlas funktsioneeribki aspekt narratiivi ajasuhete väljendamisel (vt jaotis 4). Oluline on märkida, et ajalis-aspektuaalsed suhted ei ole absoluutsed, vaid sõltuvad perspektiivist (Thelin 2002). Kirjanduslikus narratiivis kajastub see autori võimaluses kasutada ka loomaailma kujutamisel erinevat perspektiivi, mõjutades soovitud viisil lugeja kogemust. 


\section{Kirjanduslik narratiiv kui sotsiaalne praktika. Kuidas mõista fiktiivset aega?}

Oma uuringutes võtame aluseks sotsiokognitiivsusega seotud käsitlused (van Dijk 1979, 2006, Geisler 1991), vaadeldes narratiivi konstrueerimise ja interpreteerimisega seotud aspekte sotsiaalse interaktsiooni kontekstis. Vastavalt sellele lähenemisviisile paigutuvad kõik diskursuse vormid, nii suulised kui ka meid siin huvitav kirjalik diskursus, teatud sotsiokultuurilisse ja -ajaloolisse konteksti. Kirjalikud tekstid ja kirjutamispraktikad konstrueeritakse sotsiaalselt. Korduva interaktsiooni läbi kujundab kogukond tekstide suhtes teatud positsiooni või annab neile teatud väärtuse ning nii tekib kogukonna kirjutamiskultuur, s.t kujunevad tekstilised praktikad ehk viisid, mille abil luua ja edastada tähendust. See on kahesuunaline protsess - tekstid ja kirjutamispraktikad tekivad sotsiokultuurilise konteksti baasilt, kuid samal ajal osutavad sellele kontekstile ning aitavad seda luua. (Kostouli 2005)

Spetsiifilise sotsiokultuurilise praktikana eeldab ka kirjanduslik narratiiv seega lähtumist teatud konventsioonidest tähenduse loomisel ja selle interpreteerimisel. Juba Mihhail Bahtin (1987) rõhutab vajadust uurida kirjandusžanre mitte ainult kirjanduse piirides kunsti spetsiifika seisukohalt, vaid ka kui teatud diskursuse tüüpe, mida ta oma käsitluses nimetab kõnežanrideks. Eriti oluliseks peab ta primaarsete ja sekundaarsete kõnežanride erinevusi. Primaarsed kõnežanrid (nt argidialoogi repliik, kiri) on kujunenud otse kõnesuhtluses; sekundaarsed žanrid (nt teaduslik uurimus, publitsistika, kirjandusžanrid) tekivad keerukamas kultuurisuhtluses, transformeerides kujunemisprotsessis primaarseid žanre. Teisisõnu on üks peamisi küsimusi, mille Bahtin tõstatab ja mis on jätkuvalt aktuaalne, kirjandusliku diskursuse suhestumine standardse suulise kõnesituatsiooniga. Üldiselt nähakse igasuguse kirjaliku diskursuse põhiomadusena kirjutamise ja lugemise kontekstide lahutatust (Olson 2001). Keelelisi vorme kasutatakse nii, et teksti võiksid lugeda tundmatud lugejad kontekstides, mida kirjutaja täielikult ei kontrolli. Tekst omandab nii spetsiifilise vormi, mis nõuab spetsiifilist interpreteerimisviisi. Ilukirjanduse puhul on see eemaldumine kõneleja-kuulaja vahetu suhtlussituatsiooni mudelist ilmselt kõige teravam ja olemuslikum. See kajastub selgelt näiteks epistemoloogilises plaanis ja ka keelelistes erijoontes, mis eristavad sellist diskursust suulisest suhtlusest. Erinevalt reaalsusest, kus meil ei ole otsest ligipääsu teise inimese mõtetele ja tunnetele, on ilukirjanduses võimalik vahetult kujutada kolmanda isiku mentaalseid seisundeid, mõtteid, kavatsusi, tegevusmotiive jne.

Žanri kujunemise seisukohalt on huvitav jälgida, kuidas keskaegsed autorid, kes lähtuvad veel analoogiast tavapärase suulise suhtluse kogemusega, vältisid tegelase subjektiivsuse kujutamist või lasid tegelasel oma mõtteid avaldada monoloogis (valjusti mõtlemine), mis võimaldab jutustajal justkui õigustada oma teadmist teise inimese sisemaailmast (Galbraith 1995). Kirjaliku narratiivi arenedes sellised epistemoloogilised kõhklused kaovad ning lugejad ja kirjutajad hakkavad võõra subjektiivsuse kujutamist aktsepteerima sama tõepäraselt kui maastiku kirjeldust. Keelelisel tasandil kajastub see muutus siirdkõne tekkimises 17.-19. sajandil ilukirjanduslikule narratiivile ainuomase süntaktilis-stilistilise vormina just tegelase teadvuse vahetuks kujutamiseks (Banfield 1993). Siit jõuame taas loomaailma mõiste juurde (vt jaotis 1), mis just kirjandusliku narratiivi maailmaloovat või- 
met rõhutades (Herman 2002) väljendab ja samas seletab kõige paremini sellise diskursuse autonoomiat reaalse suhtlussituatsiooni suhtes. Lugu loob uue, meie reaalsest aegruumist eraldi seisva maailma, kuhu me siseneme, võttes seal toimuvat reaalsusena, mis lihtsalt eksisteerib.

Inimese kognitsioon on välja kasvanud tema bioloogilisest olemusest, kogemuse projitseerimise, osutamise ja viitamise ning interpreteerimise ehk teiseks tõlkimise võimest. Just kognitiivne narratoloogia saab arvestada neid võimeid nii tekstide looja kui lugejaga seoses. Tänu oma maailmaloovale võimele, mis võimaldab luua kõneleja minast erineva teadvussubjekti, konstrueeritakse loomaailma sisenedes ka vastav uus ajaline ja ruumiline väli. David A. Zubin ja Lynne E. Hewitt kirjeldavad seda kui deiktilist siiret, mis tähendab, et mina-siin-praegu-koordinaadid ehk deiktiline kese kantakse üle teatud punkti diskursuse maailma sees ning interpreteeritakse teksti sellest perspektiivist (Zubin, Hewitt 1995). Ajalisel teljel tähendab see, et kuigi narratiiv on kirjutatud mineviku ajavorme kasutades, ei leia need sündmused aset reaalses minevikulises ajas. Lugeja mõistab minevikuvorme kui üht signaali, et tuleb teostada deiktiline siire ning luua kirjeldatud sündmuste jaoks fiktiivne olevikuhetk loo sees ehk narratiivi nüüd-punkt, mis ei ole deiktiliselt seotud lugeja enda reaalse ajaga. See fiktsiooni tasandil konstrueeritud nüüd-punkt on deiktiline kese, mida lugeja võtab kui enda oma ning seeläbi tekib illusioon loo maailma vahetust kogemisest. Et narratiivile on omane ajaline edasiliikumine, liigub ka nüüd-punkt loo arenedes edasi. Vastavate keeleliste markeritega saab selle liikumise ka peatada või katkestada stabiilse ajalise edasiliikumise, nihutades nüüd-punkti hoopis uude ajalisse raamistikku. Lugeja loob loomaailma ajastruktuurist mentaalseid representatsioone, jälgides nüüd-punkti dünaamikat, ning - asetades end sellega määratletud deiktilisse keskmesse - liigub looga kaasa ning kogeb esitatavaid sündmusi sellest punktist lähtuvalt.

\section{Narratiivne imperfekt ja imperfektiivne narratiiv}

Aspektikategooriate funktsioneerimine narratiivis põhineb niisiis sellel, kuidas need suhestuvad nüüd-punktiga ja kuidas seda mõjutavad. Michael J. Almeida (1995) mudeli järgi funktsioneerib aspekt narratiivis järgmiselt: perfektiivselt kujutatud sündmuse ajaline viitepunkt asetub pärast kehtivat nüüd-punkti ja uus nüüd-punkt asetatakse vahetult pärast viitepunkti; seega perfektiivne aspekt liigutab nüüdpunkti edasi, kandes loo ajalist dünaamikat (vt joonis 1). Imperfektiivsed sündmused hõlmavad ajaliselt antud hetkel kehtivat nüüd-punkti; kujutatav sündmus on nüüd-punktiga samaaegne ning ajaline edasiliikumine tühistatakse.

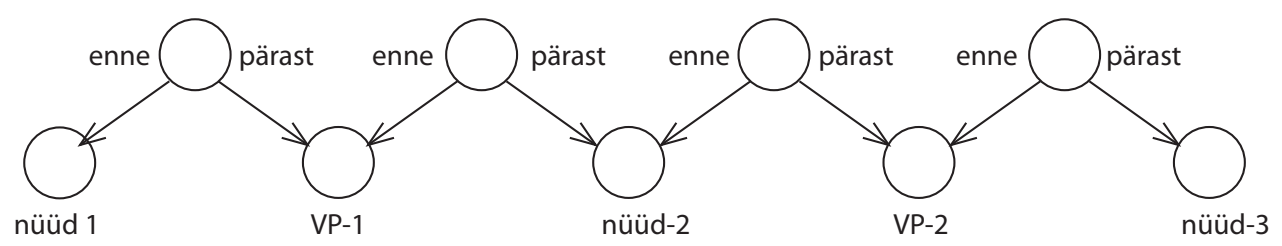

Joonis 1. Loo ajaline dünaamika (VP = viitepunkt) (Almeida 1995: 172) 
Kirjeldatud põhimõttel toimib aspekt nii keeltes, kus see on grammatiliselt väljendatud, nagu hispaania keel, kui ka eesti keeles, kus perfektiivsus või imperfektiivsus ei avaldu reeglipäraselt, vaid põhineb eelkõige verbi semantilistel aspektuaalsetel omadustel.

19. saj keskel tekib aga esmalt prantsuse- ja hiljem ka hispaaniakeelsetes kirjandustekstides uus imperfekti kasutusviis, mis ei vasta kuidagi kõnealuse vormi kanoonilisele ajalis-aspektilisele tähendusele, vaid imperfekti kasutatakse justkui perfektiivse vormi koha peal. Sellist keelekasutust on hakatud nimetama narratiivseks imperfektiks, kuigi puudub üksmeel selles osas, millised juhtumeid täpselt see mõiste hõlmab. Käesolevas uurimuses lähtume Jacques Bres' (2005) definitsioonist, mille kohaselt narratiivse imperfekti all mõeldakse imperfektiivse vormi kasutamist ajaliselt edasiliikuvate sündmuste kujutamisel. Bres on seisukohal, et narratiivses kasutuses ei muutu imperfekti aspektuaalne tähendus, vaid tegemist on perfektiivset aspekti nõudva konteksti ja imperfektiivse aspekti interaktsiooniga. Sellest vastuolust tekibki eriline stilistiline efekt.

Kuna sellist võtet kasutati algselt tüüpiliselt loo, peatüki või episoodi lõpus, on Harald Weinrich (1964) seletanud seda nähtust kui narratiivitehnilist võtet, mis aitab lugejat üleminekul loomaailma tasandilt tagasi igapäevasesse reaalsusesse. Sarnaselt imperfekti tüüpilisele kasutamisele loo alguses, mis aitab teostada deiktilist siiret loomaailma sisse, juhatab loo lõppedes imperfekt ka sujuvalt loomaailmast välja. Weinrich toob välja huvitava paralleeli Euroopa vanemas kirjanduses esineva raamjutustusega, mida võib vaadelda kui teistsugust jutustamistehnikat sama funktsiooni täitmiseks. Näiteks exemplum-i žanris kasvavad lood välja eelnevast vestlusest või arutelust, illustreerides seda, ning neile järgneb jällegi kuulajate kommentaar. Selline tehnika kajastab teadlikkust sellest, et loomaailm seisab reaalsest aegruumist mingil viisil eraldi, ja näitab samas, et üleminekut ühest teise peetakse probleemseks (vrd jaotises 3 käsitletud epistemoloogilisi küsimusi). Narratiivse imperfekti tekkes võibki Weinrichi arvates oletada kajastust sellest varasemast arusaamast, et fiktsiooni ja reaalsuse vaheliseks siirdeks on vaja mingil kujul vaheetappi.

Hiljem ei piirdu narratiivne imperfekt enam tekstiosa lõpupositsiooniga ning omandab väga mitmesuguseid kasutusi, mille narratiivitehnilist funktsiooni on raske üheselt kirjeldada. Paljude narratoloogide tähelepanu on pälvinud näiteks Anton Tšehhovi jutustamislaad, mida on nimetatud imperfektiivseks narratiiviks, kuna tavapärase perfektiivse aspekti asemel on loo kandvaid sündmusi kujutatud imperfektis, n-ö mitte-sündmustena, mis ei tõuse lugeja interpretatsioonis esiplaanile (Thelin 1990, Björklund 1993).

\section{Narratiivne imperfekt hispaania keeles ja tõlkevõimalused eesti keeles}

Uurisime narratiivse imperfekti jutustamistehnilist rolli loomaailma konstrueerimisel Benito Pérez Galdósi romaanis "Osatu", Isabel Allende romaanis "Vaimude maja”, Gabriel García Márqueze romaanis "Armastus koolera ajal”, Juan Rulfo romaanis "Pedro Páramo" ja Pío Baroja novellides, ning probleeme ja võimalusi selle funktsioonide edasiandmisel eestikeelses tõlkes. Teoste valikul on piirdutud 
kolmandas isikus esitatud narratiividega, sest minajutustuse teistsugune deiktiline ülesehitus eeldaks eraldi käsitlust. Nimetatud tekstides esines 143 narratiivse imperfekti kasutamise juhtu ning nende analüüsimisel lähtusime ajalise edasiliikumise interpreteerimise viisist (ajamäärus, põhjuslikud suhted) ja verbi semantilisest aspektist. Semantiline aspekt seab teatud piirangud aspektuaalse perspektiivi valikuks sündmuse kujutamisel. Antud juhul puudutab see eelkõige momentaanseid sündmusi, mis sisemise ajalise struktuuri puudumise tõttu eeldavad kujutamist totaalselt, s.t perfektiivselt.

Järgnevalt esitame näidete varal analüüsi tulemused, tuues välja peamised viisid, kuidas narratiivne imperfekt mõjutab loomaailmast loodavaid representatsioone, ning kuidas on see edasiantav eesti keele vahenditega. Esinemisjuhud oleme jaotanud kolme rühma vastavalt sellele, kuidas paigutub narratiivse imperfektiga väljendatud sündmus narratiivi ajateljele.

Esitatud näidetes on narratiivsed imperfektid ja nendele vastavad verbid eestikeelses tõlkes esile tõstetud. Hispaaniakeelsetes näidetes on märge verbi grammatilise aspekti kohta (IMPERF = imperfektiivne aspekt).

\subsection{Määrusega tähistatud ajaline nihe}

Vaadakem kõigepealt näiteid, kus narratiivne imperfekt tekib imperfektiivse aspekti kombinatsioonis lausealgulise ajamäärusega, mis tähistab distantsi eelmisest ajalisest punktist (nt poco después / veidi aega hiljem) või lokalisatsiooni ajateljel (nt a las ocho / kell kaheksa). Lausealguline ajamäärus on vahend nüüd-punkti nihutamiseks uude kohta (Zubin, Hewitt 1995). Nihe katkestab loo aja stabiilse edasiliikumise, tehes suurema või väiksema hüppe uude ajalisse raamistikku. Tegemist on ellipsiga, mis tekitab lahknevuse lugeja aja (teksti vastuvõtmise ajaline järgnevus) ja loo aja (loomaailma kujuteldavate sündmuste järgnevus) vahel, sest teatud loomaailma sündmusi ei ole tekstis eksplitsiitselt kujutatud, s.t teatud ajaline lõik loo tasandil jäetakse teksti tasandil vahele. Lugeja interpretatsioonis tekitab see mulje loo aja kiirest edasiliikumisest, mida veelgi süvendab sündmuste kujutamine imperfektiivsest perspektiivist.

(1) Le embarazaron, oprimiéndole en fuerte anilla horizontal de hierro sujeta a la pared, y allí, sin defensa posible, desnudo, recibió la acometida. Poco después yacía (IMPERF) aletargado en una cama con visibles apariencias de bienestar. Al fin, durmió profundamente. (BPGh: 22)

Teda hoiti kinni, alasti suruti ta seina külge kinnitatud tugevasse horisontaalsesse raudrõngasse ja seal, suutmata end kaitsta, alistus ta rünnakule. Veidi aega hiljem lebas ta uimasena, ent ilmse mõnutundega voodis. Lõpuks uinus ta sügavasti. (BPGe: 18)

Näites (1) võib näha, kuidas tänu imperfektiivsele kujutamisviisile (yacía) uues narratiivi nüüd-punktis ei koge lugeja hispaania keeles sündmusi sujuvalt kulgevatena, vaid tekib hüppeline olukorra muutus. Imperfekt kujutab sündmust partsiaalselt, s.t kirjeldatavasse sündmuste järgnevusse asetub selle sisemine faas algus- ja lõpppunktile viitamata. Et uue olukorra algust ei ole tekstis kodeeritud, kogeb lugeja seda narratiivi uues nüüd-punktis juba toimuvana, mis jätab mulje sündmuste kiirest 
vaheldumisest loo ajas ja tõstab esile kontrasti eelmise situatsiooniga. Antud näide on tüüpiline, kuna imperfekti on sellise efekti loomiseks kasutatud dramaatilise stseeni ja samuti kogu peatüki lõpus. Ka eesti keeles on siin kasutatud seisundiverbi (lebas), mida tüüpiliselt mõistetakse imperfektiivsena, mistõttu vastav sündmuste ajalis-aspektiline kujutusviis on hästi edasiantav.

(2) Se fueron de viaje a Italia y a los dos días de embarcarse, Esteban se sentía (IMPERF) enamorado como un adolescente, [---] (IAh: 89)

Nad läksid pulmareisile Itaaliasse ja kaks päeva pärast laevale asumist tundis Esteban, et oli armunud nagu nooruk, [---] (IAe: 111)

Erinevalt eelmisest näitest jääb näites (2) eesti keeles sündmuse aspektuaalsus ebamääraseks, sest tundma võib tähistada nii momentaanset sündmust kui ka staatilist seisundit, millest tulenevalt tajutakse sündmust vastavalt kas pigem perfektiivselt või imperfektiivselt. Seetõttu kogeb lugeja eestikeelse teksti põhjal stseeni neutraalsemalt. Et lugeja looks sellest täpsemini originaalile vastava mentaalse representatsiooni, võiks eesti keeles lisada juba, mis rõhutaks muutuse kiirust, vrd (4). Loo ülesehituse seisukohast ei ole siiski ka hispaania keeles siin kontrast nii terav kui näites (1), sest narratiivne imperfekt ei rõhuta siin piiri sündmuste arenguliinide, stseenide või tekstiosade vahel.

(3) Se había ido a errar por las escolleras, y estuvo recitando versos de amor contra el viento, llorando de júbilo, hasta que acabó de amanecer. A las ocho estaba sentado (IMPERF) bajo los arcos del Café de la Parroquia, alucinado por la vigilia, tratando de concebir un modo de hacerle llegar su bienvenida a Fermina Daza, cuando se sintió sacudido por un estremecimiento sísmico que le desgarró las entrañas. (GGMh: 148)

Ta tuias muulil edasi-tagasi, luges lõõtsuvasse tuulde lembevärsse ja nuttis rõõmust, kuni läks valgeks ja hommik kätte jõudis. Kell kaheksa istus ta kohviku võlvlaega terrassil, magamatusest uimane, ja püüdis välja mõelda, kuidas peaks Fermina Dazale kätte toimetama oma tervitused kui äkki oleks nagu maavärin terve tema sisikonna segamini raputanud. (GGMe: 99)

Ka näites (3) võib narratiivse imperfekti jutustamistehniliseks funktsiooniks pidada kontrasti rõhutamist, kuigi siin mitte muutuse kujul võrreldes eelneva olukorraga, vaid loo arengus äärmiselt olulise järgneva sündmuse suhtes. G. García Márqueze jutustamislaad romaanis kujutab loomaailma üldiselt neutraalsest, märkamatust vaatepunktist, tungimata tegelaste sisemisse subjektiivsesse ruumi ning kasutamata ka loomaailmast selgelt väljaspool asuva vaatepunkti võtet. Lugeja aeg kulgeb üldiselt paralleelselt loo ajaga. Narratiivne imperfekt on seetõttu kõnealuses tekstis üsna erandlik. Käsitletaval juhul see justkui aeglustab tegelase ruumiliste liikumiste ja tegevuste järgnevuse, sest ajaliselt liigub lugu edasi (a las ocho / kell kaheksa), kuid tegevus on kujutatud staatiliselt (estaba sentado, samuti eesti keeles kasutatud seisundiverb istus). See eelmiste perfektiivsete sündmuste jadas esilekerkiv imperfektiiviga vormistatud stseen ja selle staatika valmistavad lugeja ette järgmiseks ootamatuks sündmuseks, mis moodustab kogu eelmise tegevusliini kulminatsiooni. See tõuseb lugeja loomaailma tajumisel jõuliselt esile, pannes teda 
sel viisil vahetumalt kogema tegelase vapustust. Huvitav on see näide seetõttu, et eesti tekstis on tõlkija kirjeldatud efekti tugevdamiseks kasutanud mõttekriipsu, mis tõstab järgnevat esile.

(4) El Majito se dejó ir con grave paso por la calle de Moratines abajo. Era el día ventoso, frío y seco, hijo maldito de la malditísima primavera de Madrid. La pluma del ros del Majito - porque una pluma de pavo tenía se torcía con la fuerza del viento. [---]

En la calle de Ercilla tenía (IMPERF) ya un séquito de seis muchachos; en la del Labrador ya se le había incorporado una partida de diecisiete, entre hembras y varones, siendo las primeras, icosa extraña!, las que más bulla metían. (BPGh: 92-93)

Keku läks tähtsal sammul mööda Moratinese tänavat. Päev oli tuuline, külm ja kuiv, jõleda Madriidi kevade jõle sünnitis. Sulg Keku mütsil - seal oli nimelt paabulinnusulg - kõverdus tuule käes. [---]

Ercilla tänavas oli tal juba kuuest poisist koosnev saatjaskond; Labradori tänavas olid temaga ühinenud juba seitseteist tüdrukut ja poissi, kusjuures esimesed - imelik asi! - kõige rohkem lärmi tegid. (BPGe: 75-76)

Et deiktilise välja erinevad parameetrid (aeg, ruum, psühholoogiline vaatepunkt) on omavahel tihedalt seotud, mõjutavad ühe komponendiga eksplitsiitselt teostatavad operatsioonid sageli implitsiitselt ka teisi. Eriti otsene seos on ruumilise ja ajalise asukoha vahel liikumise puhul, kuna liikumine toimub ajas. Näites (4) on fookuses loomaailma ruumis liikuv tegelane ja lugeja representatsioon antud stseenist lähtub temaga kaasaliikuvast deiktilisest punktist. Kui lausealguline määrus nihutab deiktilise keskpunkti ruumis uude kohta (Ercilla tänavas), toimub nihe ka ajalisel teljel. Seega võib nüüd-punkti edasi nihutada ka kohamäärus ning koos imperfektiivse aspektiga (nii hispaania keeles kui ka eesti keeles tänu seisundiverbi semantilisele aspektile) saavutatakse samasugune kujutusviis, nagu nägime eelmistes näidetes. Näites (4) ei ole narratiivne imperfekt stseeni või tekstiosa üleminekut või pöördepunkti tähistavas positsioonis, mis seda veelgi esile tõstaks, kuid olukorra kiire muutuse rõhutamiseks on kasutatud ka määrust ya / juba.

(5) Y poco después se volvía a cerrar (IMPERF) la triste alcoba, y retirándose personas y luces, todo quedaba (IMPERF) en silencio y soledad tristísima. (BPGh: 154)

Ja varsti pärast seda suleti taas kurb magamistuba, ning et inimesed ja valgus lahkusid, vajus kõik vaikusse ning ülikurba üksindusse. (BPGe: 125)

Erinevalt eelmistest näidetest eeldab näites (5) sündmuste aspektiline iseloom (momentaansus) nende kujutamist perfektiivselt. Nii mõistetakse nende kujutusviisi ka eestikeelses tõlkes (suleti puhul märgib täissihitis selgelt perfektiivsust), kuid hispaania keeles on neid kirjeldatud imperfektiivse vormiga. Hispaania keeles tekib nii kontrast imperfekti ajalis-aspektuaalse tähenduse ja konteksti vahel, kus ajamäärus viib lugeja ajaliselt edasi uude nüüd-punkti ning sündmused on mõistetavad totaalselt, lõpule jõudnutena, ning põhjuslikult üksteisele järgnevatena. Kuid 
imperfekti vorm peatab ajalise edasiliikumise määrusega tähistatud nüüd-punktis; järgmiste verbidega kirjeldatu ei asetu ajateljel edasi selle punkti järele (nagu seda teeks eeldatav perfektiivne aspekt), vaid need jäävad seotuks sama ajalise punktiga. Loo dünaamiline kulg pidurdub, fookus ei ole enam sündmuste järgnevusel, vaid justkui distantseerutakse narratiivi ajateljest ning stseen omandab staatilise iseloomu. Nii võtab narratiivne imperfekt kokku ja lõpetab eelneva dramaatilise süžeeliini ning samuti kogu peatüki. Selline funktsioon on teksti lõpupositsioonis esinevale narratiivsele imperfektile tüüpiline (vt jaotis 4).

Kuna narratiivne imperfekt ilmub kontrastina perfektiivset aspekti eeldava kontekstiga, võib selle eripärane tähendus avalduda suuremal või vähemal määral, sõltuvalt kontekstiliste eelduste tugevusest (Bres 2005). Verbi momentaanne semantiline aspekt loob tugeva eelduse sündmuse kujutamiseks perfektiivselt, seetõttu on näite (5) puhul tekkinud kontrast teravam kui eelmistes näidetes ning ka selle mõju ajalisele ja vaatepunktilisele interpretatsioonile tugevam.

\subsection{Põhjuslike suhete alusel järeldatav ajaline edasiliikumine}

Sageli ei ole edasiliikumine narratiivi ajateljel küll kodeeritud keeleliste markerite abil, kuid selline interpretatsioon on siiski järeldatav teadmiste põhjal, mis lugejal on maailmast, s.t sündmustest ja nende omavahelistest seostest, eriti põhjussuhetest. Nendel juhtumitel ei ole tegemist hüppelise ajalise nihkega, vaid sujuva ajalise edasiliikumisega. Kuigi imperfekti vorm tüüpiliselt paigutab sündmuse kehtivasse nüüd-punkti, tühistades edasiliikumise, järeldub käsitletavates näidetes põhjusseostest sündmuste ajaline järgnevus.

(6) Isidora puso atención, y, en efecto, del fondo invisible venía (IMPERF) un rumor hondo y persistente, [---] (BPGh: 48)

Isidora pingutas tähelepanu, ja tõepoolest, ruumi nähtamatust kaugusest tuli pidev, sügav heli [---] (BPGe: 39)

Näites (6) paigutub kirjeldatud heli lugeja mentaalses representatsioonis pärast sündmust Isidora pingutas tähelepanu. Loo ülesehituses ei tõuse kõnealune imperfektikasutus kuigivõrd esile, kuid näitab ilmekalt narratiivi ajastruktuuri seost vaatepunktiga. Kuna sündmusi kujutatakse tegelase vaatepunktist, hakkab ka lugeja kirjeldatud heli justkui kuulma alles siis, kui tegelane on selle olemasolu märganud. Samasuguse interpretatsiooni annab ka eestikeelne tõlge.

(7) El sol se fue volteando sobre las cosas y les devolvió su forma. La tierra en ruinas estaba frente a él, vacía. El calor caldeaba su cuerpo. Sus ojos apenas se movían; saltaban de un recuerdo a otro, desdibujando el presente. De pronto su corazón se detenía (IMPERF) y parecía como si también se detuviera el tiempo. Y el aire de la vida. (JRh: 280)

Päike tiirles asjade kohal ja moondas nende kuju. Varemetes, tühi maa oli ta ees. Kuumus soojendas ta keha. Ta silmad liikusid vaevu; nad hüppasid ühelt mälestuselt teisele, pühkides oleviku minema. Äkki jäi ta süda seisma ja paistis, nagu oleks ka aeg ja eluhingus seisma jäänud. (JRe: 90) 
Erinevalt näitest (6) on näites (7) nii hispaania keeles kui ka eestikeelses tõlkes tegemist momentaanse verbiga (se detenía / jäi seisma), mis eeldaks tüüpiliselt kujutamist perfektiivsena. Siiski on hispaania keeles kasutatud imperfekti vormi. Selle vastuolu tõttu tõuseb sündmus, milleks on peategelase Pedro Páramo surm, loo arengus esile. Kuna imperfekt ei loo narratiivi kujutamisel uut nüüd-punkti, peatab see ajalises plaanis romaani lõpus loo kulu. Ka siin võib samas näha imperfekti ajalise tähenduse seost vaatepunktiga, paigutades selle tegelase subjektiivsesse ruumi. Üldiselt on romaani vältel Pedro Páramot kujutatud pigem objektiivsest vaatepunktist, kuid lõpustseenis samastutakse tema subjektiivse teadvusega, mis omakorda tõstab kõnealuse stseeni loomaailma kujutamisel esile. Eestikeelses tõlkes selline aspektiline, ajaline ja vaatepunktiline kontrast ei avaldu.

Loomaailma representatsiooni eriti tugevalt mõjutavad ajalised ja sellega seotud ruumilised ning eelkõige vaatepunktilised modifikatsioonid tekivad narratiivsete imperfektide pikemate jadade korral. Vaatepunkti konstrueerimisel mängib lisaks teatud markerite olemasolule lauses rolli ka selle paiknemine kontekstis, s.t eelmiste lausete subjektiivsus või objektiivsus (Wiebe 1994). Imperfektiivne aspekt on kontekstitundlik vaatepunkti marker, mistõttu pikemas imperfektiga kujutatud tekstilõigus avaldub selle vaatepunkti loov potentsiaal tugevamalt kui üksiku verbi puhul.

(8) El viejo se asomó a la boca de la caverna.

- iZagal, zagal! - gritó, con desesperación.

Nada, no se oía (IMPERF) nada.

- iZagal! iZagal!

Parecía oírse (IMPERF) mezclado con el murmullo del viento un balido doloroso que subía desde el fondo de la caverna.

Loco, trastornado, durante algunos instantes, el pastor vacilaba (IMPERF) en tomar una resolución; luego se le ocurrió pedir socorro a los demás cabreros, y echó a correr hacia el castillo. (PBh: 74)

Vanamees kummardus üle kuristikuserva.

"Poiss, poisu!" karjus ta meeleheitlikult.

Mitte midagi polnud kuulda, mitte ühtegi häält.

"Poiss! Poiss!"

Alt kuristiku sügavusest, segamini tuule sosinaga, näis kostvat üksainus valus oie.

Juhmistunud, peaaegu mõistuse kaotanud, oli karjus mõne silmapilgu vältel võimetu midagi otsustama. Siis sähvatas ta peast läbi, et tuleb teisi kitsekarjuseid appi kutsuda, ja ta pistis lossi poole jooksu. (PBe: 40)

Näites (8) kujutatakse novelli pöördepunktiks olevat dramaatilist sündmust, kus vana karjuse poeg kukub kuristikku. Kuna üks sündmus toimub reaktsioonina teisele, on järeldatav, et need paigutuvad ajas üksteise järele, kuid hispaania keeles on neid kujutatud imperfekti vormis. Selle tulemusel loo ajaline kulg justkui peatub, stseen omandab staatilise iseloomu, mis teeb lugejale tajutavaks valitseva pinge. Lugeja interpreteerib stseeni tegelase subjektiivse deiktilise keskmega samastudes, kogedes tema meeleheidet ja peataolekut. Eesti keeles ei tule subjektiivne vaatepunkt nii selgesti esile.

Järgnevalt esitame kaks näidet B. Pérez Galdósi romaanist "Osatu”. Selles romaanis loob autor fiktiivse jutustaja kuju, pöördudes aeg-ajalt otseselt lugeja 
poole, esitades oma teadmisi loost piiratuna (ma ei tea kindlasti, kas see oli samal päeval) jne. Sel viisil konstrueeritakse loost väljaspool asuva jutustaja deiktiline kese. Selle tulemusel jutustatakse sündmustest suurel määral justkui nähtuna loomaailmast väljaspool asuvast vaatepunktist. Lugeja distantseeritakse seega loomaailmast. Sama funktsiooni täidab romaanis sageli ka narratiivne imperfekt.

(9) iCon qué inocente confianza y abandono iban los dos, en familiar pareja, por los senderos torcidos que conducen desde el camino de Aragón a Pajarillos! Bajaban (IMPERF) a las hondonadas de tierra sembrada de mies raquítica; subían (IMPERF) a los vertederos, donde lentamente, con la tierra que vacían los carros del Municipio, se van bosquejando las calles futuras; pasaban (IMPERF) junto a las cabañas de traperos hechas de tablas, puertas rotas o esteras, y blindadas con planchas que fueron de latas de petróleo; luego se paraban (IMPERF) a ver muchachos y gallinas escarbando en la paja; daban vueltas (IMPERF) a los tejares; se detenían (IMPERF), se sentaban (IMPERF), volvían a andar (IMPERF) un poco, sin prisa, sin fatiga. (BPGh: 71)

Millise süütu usalduslikkuse ja sundimatusega läksid nad nagu kaks lähedast sõpra mööda käänulisi radu, mis viivad Aragóni teelt Pajarillosele! Nad laskusid nõgudesse, kus kasvas kidurat teravilja, tõusid prügimägedele, kus muld, mida siia vedasid linnavalitsuse vankrid, hakkas pikkamisi kujundama tulevasi tänavaid; möödusid kaltsukorjajate onnidest, kaetud vanade petrooleumivaatide plekiga; nad peatusid, et vaadata poisikesi ja õlgedes siblivaid kanu; möödusid tellisetehastest; jäid siin-seal peatuma, võtsid istet, läksid jälle edasi, ruttamata, väsimata. (BPGe: 58)

Näites (9) kujutatud tegevused paiknevad ajas üksteise järel. Kuna hispaania keeles on neid kujutatud imperfektiivses aspektis, on nad tajutavad kui samaaegsed ühe ja sama nüüd-punktiga, s.t nad kõik iseloomustavad teatud üht ajalist punkti loos. Erinevad tegevused on koondatud ühtsesse ajalisse raami, mis on fookuses, ning sündmuste omavahelised suhted selle raamistuse sees jäävad tagaplaanile. Selliselt modifitseeritud ajalised suhted avaldavad mõju ka ruumilisele mõõtmele ja vaatepunktile. Lugeja ei liigu tegelaste ja nende liikumisega kaasa, vaid näeb kogu episoodi justkui tervikuna kuskilt eemalt. Seda võiks piltlikult võrrelda kõrgusest linnale avaneva vaatega, kus tänavad on kõik samaaegselt näha nagu staatilisel pildil. Kui aga asume linnas sees, saame erinevaid ruumilisi punkte näha ainult ajaliselt üksteise järel, ühest teise liikudes. Teisisõnu deiktiline kese, kust lugeja sündmusi näeb, on konstrueeritud sündmusteliinist väljaspool, distantseerudes sellest. Loo struktuuris täidab kõnealune ajaliselt ja vaatepunkti poolest modifitseeritud lõik lisaks tüüpilist rolli märkida üleminekut uuele teemaarendusele. Ka eestikeelses tõlkes jääb kirjeldatud tegevuste täpne omavaheline järjestus tegelikult määramatuks, neid on kujutatud läbisegi (tõlkija on ilmselt seepärast välja jätnud originaalis esineva luego 'siis, seejärel', mis märgiks täpset ajalist suhet). Hispaaniakeelses tekstis tekkiv ajaline ja vaatepunktiline efekt ei ole siiski edasiantav.

(10) Don José, a quien las horas se le hacían siglos, no pensaba en apuntar en el Diario ni en el Mayor los gastos extraordinarios de aquel día. Por 
la tarde ocupábase (IMPERF) de instalar la mesa en la sala, por ser el comedor muy pequeño para tan gran festín. Después se miraba (IMPERF) diecinueve veces al espejo, se acicalaba (IMPERF), y en el colmo ya del regocijo, les quitaba (IMPERF) a los chicos del tercero el tambor con que atronaban la casa toda, y tocaba (IMPERF) por los pasillos con furor y denuedo, seguido de la turba infantil y por ésta con alegres chillidos aclamado. (BPGh: 192)

Don José, kellele tunnid tundusid sajanditena, ei mõtelnudki kanda majapidamistarvete raamatusse ega pearaamatusse selle päeva erakordseid kulusid. Õhtupoolikul oli ta ametis söögilaua ülesseadmisega saali, sest söögituba jäi nii suure pidusöömingu jaoks väikeseks. Siis vaatas ta oma paarkümmend korda peeglisse, klanis end, ja kui rõõmutuju haripunkti tõusis, võttis neljanda korruse poistelt trummi, millega need kõrvulukustavalt põristasid, nii et kogu maja kajas, ja mängis kõigis koridorides tohutu vaimustuse ning hooga, saadetuna lastekarjast, kes talle rõõmsa kilkamisega oma heakskiitu avaldas. (BPGe: 157)

Näites (10) on samuti tegemist sündmuste järgnevusega, mida on hispaania keeles kujutatud imperfekti vormis. Eelmise näitega samal viisil tekib ka siin distantseerunud vaatepunkt. Kirjeldatud episoodi ei näe lugeja selle sujuvas kulgemises, narratiivi ajateljel tegelasega kaasa liikudes ja tema teadvuse ja tunnetega samastudes, vaid tegelast jälgitakse justkui eemalt, ilma empaatiata, mis tõstab esile tema õhina naeruväärsuse. Samal ajal on imperfekti kasutamisel antud juhul ka narratiivi ülesehitav roll, tõstes tekstis stilistiliselt esile stseeni, mida võib pidada eelnevalt kujutatud sündmuste kulminatsiooniks. Eestikeelse teksti lugeja interpreteerib stseeni neutraalse sündmuste järgnevusena.

\subsection{Narratiivne imperfekt ja habituaalsus}

Analüüsitud tekstides leidus juhtumeid, kus hispaania keeles imperfekti vormis kujutatud stseen eemaldub narratiivi ajateljelt. Selle ajaline lokalisatsioon teiste loo sündmuste suhtes hägustub ning lükkub ajaliselt määramatule tagaplaanile, omandades habituaalse tähenduse. Habituaalsus kuulub imperfektiivse aspekti tüüpiliste tähenduste hulka, kuid käsitletavatel juhtudel ei ole siiski tegemist imperfekti standardse kasutusega, sest üleminek toimub sujuvalt ning õieti on kogu stseen tajutav justkui seguna konkreetsest ühekordsest sündmustejadast ja habituaalsest kirjeldusest.

(11) Sorprendamos a don Manuel José Ramón Pez (o del Pez) cuando, recién abandonadas las ociosas plumas, entraba (IMPERF) en su despacho a enterarse de varios asuntos, ajenos a su empleo, [---]. Envuelto en su abrigadora bata, calados los lentes o quevedos, [---], revolvía (IMPERF) cartas, consultaba (IMPERF) notas, hojeaba (IMPERF) memorándums, ordenaba (IMPERF) in mente lo que no tenía orden, hacía (IMPERF) cálculos, esbozaba (IMPERF) proyectos, trazaba (IMPERF) planes. La frase y el guarismo se entrecruzaban en su cerebro, [---]; abismábase (IMPERF) en meditaciones; después, tarareando una cancioncilla, pasaba (IMPERF) 
la vista por los periódicos de la mañana, daba (IMPERF) algunas órdenes a sus escribientes y se ocupaba (IMPERF) un poco de teatros y diversiones. (BPGh: 176)

Vaadakem don Manuel José Ramón Pezi (või del Pezi), kui ta hommikuti lahkus laiskusele meelitavailt sulgpatjadelt ja astus oma kabinetti tutvuma mitmesuguste tema ametile võõraste asjadega, [---]. Soe hommikumantel ümber, näpitsprillid ninal, [---], soris ta kirju, vaatas ülestähendusi, lehitses märkmikku, korraldas in mente seda, milles polnud korda, arvutas, visandas projekte, nuputas plaane. Sõnad ja arvud ristusid tema ajus, [---]; ta süvenes mõtisklustesse; seejärel heitis laulu ümisedes pilgu hommikulehtedesse, tegi mõned korraldused oma kirjutajaile ja tegeles siis pisut teatrite ning meelelahutuskohtadega. (BPGe: 144)

Näites (11) kirjeldatakse tegevusi, mis loogiliselt toimuvad üksteise järel. Nende järjekord jääb kas määramatuks või on eksplitsiitselt väljendatud määrusega después/seejärel; tõlkija on eesti keeles lisanud ka sïs. Erinevalt näidetest (9) ja (10), kus on samuti tegemist üksteisele järgnevate sündmustega, võib siin kirjeldatud tegevustele anda habituaalse tõlgenduse, kuna tegemist on uue peatüki algusega ja stseeni ajaline paigutus loomaailmas jääb ebamääraseks. Tõlkija on eesti keeles habituaalsust eksplitsiitselt väljendanud, lisades määruse hommikuti. Samas luuakse pöördumisega lugeja poole (sorprendamos ... / vaadakem ...) nii hispaania kui ka eesti keeles konkreetne vaatepunkt, justkui asuks lugeja koos jutustajaga kusagil lähedal ja jälgiks stseeni sealt. See loob mulje, et vaatame tegelast ühel konkreetsel, loomaailma ajateljel teatud kohta omaval hommikul, mis on vastuolus habituaalsusega. Hispaania keeles eksisteerivad paralleelselt mõlemad tõlgendusvõimalused. Eesti keeles on tõlkija otsustanud habituaalsuse kasuks. Vastavat määrust lisamata ei kerkiks habituaalne interpretatsioonivõimalus esile.

\section{Kokkuvõte}

Diskursiivne lähenemine kognitsioonile kui inimese meelte, taju ja võimete uurimisele tähendab tekstide loomisel ja tõlkimisel ning lugeja mentaalsete representatsioonide kujunemisel arvestamist teadmistega maailma kohta ning sotsiokognitiivsete aspektidega. Kognitiivse narratiivi vaimus peaksid nii originaaltekst kui tõlge tooma lugejani kogemuse tõlgendamist võimaldavast tähenduste paljususest ja loomaailma dünaamilisest vastasmõjust.

Analüüsitud näidete põhjal võime narratiivse imperfekti üldiseks iseloomustamiseks öelda, et selle jutustamistehnilised omadused hispaania keeles põhinevad kontrastil, mis väljendub nii paradigmaatilises lõikes, olles vastuolus antud kohal eeldatava perfektiivse aspektiga, kui ka süntagmaatiliselt, tõstes sündmuse või stseeni esile ümbritseva kontekstiga võrreldes. Kontrasti tulemuseks ei ole siiski vaid lugeja tähelepanu teravdamine loo kulminatsioonis või pöördepunktis, vaid narratiivne imperfekt annab sündmusele imperfektiivse perspektiivi ja seega toob kaasa muutused selle suhestumises narratiivi nüüd-punktiga. Tulemuseks võib olla sündmuste kiirendatud esitus või vastupidi - loo kulgemise aeglustumine ja 
distantseerumine selle ajateljest. Muutunud ajaline struktuur toob kaasa muutusi ka loo interpretatsiooni teistes parameetrites, eelkõige vaatepunktis, mis mõjutab loo lugejapoolset kogemist enamgi kui sündmuste ajaline paigutus. Narratiivse imperfektiga luuakse sageli neutraalsest märkamatust perspektiivist erinev vaatepunkt, mis võib samastuda tegelasega või kuuluda justkui kõrvalseisjast vaatlejale. Eesti keeles on narratiivse imperfektiga loodud sündmuste kujutusviis üldiselt paremini edasiantav juhul, kui kontrast kontekstiliste eeldustega on nõrgem (nt seisundiverbide puhul). Mõnikord saab kontrasti väljendada teiste vahenditega, isegi kirjavahemärkidega. Eesti keeles väljendamatud modifikatsioonid tekivad eriti siis, kui vastuolu kontekstiliste eeldustega on suur (momentaansed verbid), ja pikemate narratiivses imperfektis olevate järgnevuste korral.

Kuigi käesolevas artiklis käsitletud näidete põhjal võiks väita, et grammatilise aspektikategooria olemasolu annab hispaania keelele suuremad väljendusvõimalused kui on eesti keelel, tuleb märkida, et teisest küljest tähendab aspekti väljendamise vältimatus ka teatud piirangut. Selle mõju narratiivi loomisel oleks huvitav uurida eesti-hispaania suunalise tõlkevõrdluse kaudu, kuid otsetõlgete puudumise tõttu ei ole see praegu kahjuks võimalik.

\author{
Materjali allikad \\ BPGe = Pérez Galdós, Benito 1979. Osatu. Tallinn: Eesti Raamat. (Eesti keelde tõlkinud \\ Aita Kurfeldt.) \\ BPGh = Pérez Galdós, Benito 2005. La desheredada. Madrid: Alianza Editorial. \\ GGMe = García Márquez, Gabriel 1995. Armastus koolera ajal. Tallinn: Varrak. (Eesti keelde \\ tõlkinud Marin Mõttus.) \\ GGMh = García Márquez, Gabriel 2006. El amor en los tiempos del cólera. Barcelona: \\ Debolsillo. \\ IAe $=$ Allende, Isabel 1992. Vaimude maja. Tallinn: Eesti Raamat. (Eesti keelde tõlkinud \\ Ruth Lias.) \\ $\mathrm{IAh}=\quad$ Allende, Isabel 1992. La casa de los espíritus. Barcelona: Plaza \& Janés. \\ $\mathrm{JRe}=$ Rulfo, Juan 1979. Pedro Páramo. Tallinn: Perioodika. (Eesti keelde tõlkinud Tatjana \\ Hallap.) \\ $\mathrm{JRh}=\quad$ Rulfo, Juan 1968. El llano en llamas; Pedro Páramo. La Habana: Casa de las Amé- \\ ricas. \\ $\mathrm{PBe}=$ Baroja, Pío 1979. Kuristik. - Vagabund Elizabide. Tallinn: Perioodika. (Eesti keelde \\ tõlkinud Asta Põldmäe.) \\ $\mathrm{PBh}=$ Baroja, Pío 1988. La sima. - Mari Belcha y otros cuentos. Madrid: Ediciones de la \\ Torre.
}

\title{
Viidatud kirjandus
}

Almeida, Michael J. 1995. Time in narratives. - Judith F. Duchan, Gail A. Bruder, Lynne E. Hewitt (Eds.). Deixis in Narrative: A Cognitive Science Perspective. Hillsdale, New Jersey: Lawrence Erlbaum Associates, 159-189.

Bahtin, Mihhail 1987. Valitud töid. Tallinn: Eesti Raamat.

Banfield, Ann 1993. Where epistemology, style, and grammar meet literary history: The development of represented speech and thought. - John A. Lucy (Ed.). Reflexive Language, Reported Speech and Metapragmatics. Cambridge: Cambridge University Press, 339-364. 
Björklund, Martina 1993. Narrative Strategies in Čechov's The Steppe: Cohesion, Grounding and Point of View. Åbo: Åbo Akademi Univiversity Press.

Bres, Jacques 2005. L'imparfait dit narratif. Paris: CNRS-Editions.

Bruner, Jerome 1986. Actual Minds, Possible Worlds. Cambridge, Mass.: Harvard University Press.

Bybee, Joan L.; Dahl, Östen 1989. The creation of tense and aspect systems in the languages of the world. - Studies in Language, 13 (1), 51-103.

Chatman, Seymour 1990. Coming to Terms: The Rhetoric of Narrative in Fiction and Film. Ithaca, London: Cornell University Press.

Comrie, Bernard 1993. Tense. Cambridge: Cambridge University Press.

Comrie, Bernard 1995. Aspect: An Introduction to the Study of Verbal Aspect and Related Problems. Cambridge: Cambridge University Press.

Dijk, Teun A. van 1979. Cognitive processing of literary discourse. - Poetics Today, 1, 143-160.

Dijk, Teun A. van 2006. Discourse, context and cognition. - Discourse Studies, 8 (1), 159-177.

Fleischman, Suzanne 1991. Toward a theory of tense-aspect in narrative discourse. - Jadranka Gvozdanovic, Theo A. J. M. Janssen (Eds.). The Function of Tense in Texts. Amsterdam etc.: North-Holland, 75-97.

Galbraith, Mary 1995. Deictic shift theory and the poetics of involvement in narrative. - Judith F. Duchan, Gail A. Bruder, Lynne E. Hewitt (Eds.). Deixis in Narrative: A Cognitive Science Perspective. Hillsdale, New Jersey: Lawrence Erlbaum Associates, 19-59.

Geisler, Cheryl 1991. Toward a sociocognitive model of literacy: Constructing mental models in a philosophical conversation. - Charles Bazerman, James Paradis (Eds.). Textual Dynamics of the Professions: Historical and Contemporary Studies of Writing in Professional Communities. Madison: University of Wisconsin Press, 171-190.

Genette, Gérard 1972. Figures III. Paris: Éditions du Seuil.

Gurevitš, Aron 1992. Keskaja inimese maailmapilt. Tallinn: Kunst.

Herman, David 2000. Narratology as a cognitive science. - Image \& Narrative, 1 (1). http:// www.imageandnarrative.be/index.htm (07.09.2009).

Herman, David 2002. Story Logic: Problems and Possibilities of Narrative. Lincoln: University of Nebraska Press.

Kostouli, Triantafillia 2005. Making social meanings in contexts. - Triantafillia Kostouli (Ed.). Writing in Context(s). Textual Practices and Learning Processes in Sociocultural Settings. New York: Springer, 1-26.

Metslang, Helle 1994. Temporal relations in the predicate and the grammatical system of Estonian and Finnish. Oulun yliopiston suomen ja saamen kielen laitoksen tutkimusraportteja, 39. Oulu: University of Oulu.

Olson, David R. 2001. What writing is. - Pragmatics \& Cognition, 9 (2), 239-258.doi:10.1075/ pc.9.2.04ols

Reichenbach, Hans 1947. Elements of Symbolic Logic. New York: Macmillan.

Shedletsky, Lenny 2008. Cognition. - Wolfgang Donsbach (Ed.). The International Encyclopedia of Communication. Vol. II. Malden, MA, USA, Oxford, UK, Careton, Victoria, Australia: Blackwell Publishing Ltd., 541-543.

Zubin, David A.; Hewitt, Lynne E. 1995. The deictic center: A theory of deixis in narrative. Judith F. Duchan, Gail A. Bruder, Lynne E. Hewitt (Eds.). Deixis in Narrative: A Cognitive Science Perspective. Hillsdale, New Jersey: Lawrence Erlbaum Associates, $107-128$.

Talmy, Leonard 1995. Narrative structure in a cognitive framework. - Judith F. Duchan, Gail A. Bruder, Lynne E. Hewitt (Eds.). Deixis in Narrative: A Cognitive Science Perspective. Hillsdale, New Jersey: Lawrence Erlbaum Associates, 421-460. 
Thelin, Nils B. 1990. Verbal aspect in discourse: On the state of the art. - Nils B. Thelin (Ed.). Verbal Aspect in Discourse. Amsterdam: Benjamins, 3-88.

Thelin, Nils B. 2002. Biopragmatism, space/time cognition, and the sense of language. - Michael Shapiro (Ed.). The Peirce Seminar Papers, Vol. 5. New York: Berghahn Books, 1-68.

Uspenskij 1970 = Успенский, Борис Андреевич 1970. Поэтика композиции: структура художественного текста и типология композиционной формы. Москва: Искусство.

Weinrich, Harald 1964. Tempus: besprochene und erzählte Welt. Stuttgart: Kohlhammer. Wiebe, Janyce 1994. Tracking point of view in narrative. - Computational Linguistics, 20 (2), 233-287.

Yli-Vakkuri, Valma 1994. Tempuksenkäyttö suomalaisessa ja virolaisessa fiktiivisessä tekstissä. - Karl Pajusalu, Valma Yli-Vakkuri (toim.). Lähivertailuja 7: Suomalais-virolainen kontrastiivinen seminaari Tammivalkamassa, 5.-7.1993. Turku, 136-149.

Triin Lõbus (Tartu Ülikool) on õppinud hispaania filoloogiat, tõlkinud hispaania keelest eesti keelde, uurinud aega ja aspekti narratoloogia ja kontrastiivse lingvistika raamistuses.

triin.lobus@mail.ee

Silvi Tenjes (Tartu Ülikool) on uurinud käeliigutusi, kõnekeelt ja kommunikatsiooni, metafoorsust, ruumisemantikat. Uurib suhtlust multimodaalses kommunikatsioonis ning sotsiaalses interaktsioonis. Huvitub tegevusrepresentatsiooni seosest tajuruumiga liigutuste sooritamiseks ning õppimiseks.

silvi.tenjes@ut.ee 


\section{TIME OF NARRATIVE AND TIME OF TRANSLATION: A DISCURSIVE APPROACH}

Triin Lõbus, Silvi Tenjes

University of Tartu

The current article explores temporal relations in fictional narratives by comparing original Spanish works with their translations in Estonian. The focus lies on the role of the so-called narrative imperfect as a device of style and narrative technique in Spanish. Furthermore, the article endeavours to address the problems and possibilities associated with transmitting the narrative imperfect in Estonian in such a way that the reader is able to experience the storyworld in the most similar way possible with respect to its original construction by the author in Spanish. The study is based on a sociocognitive approach. Accordingly, fictional narrative is seen as a sociocultural practice expected to follow certain conventions in creating and interpreting meaning.

Interpreting temporal relations in fictional narrative requires relocation to the narrative now-point located within the storyworld. Therefore, the functioning of aspectual categories in a narrative concerns its interaction with this now-point. The narrative imperfect involves the rather exceptional use of the imperfective aspect in the case of a temporal progression of narrative now-point. The present study is intended to point out the main ways of how narrative imperfect can affect mental representations of the storyworld. In addition, the possibilities of expressing the same modifications by means of the Estonian language are discussed. The results of the analysis show that the use of narrative imperfect in Spanish is generally characterized by its contrast with the presupposed use of perfective aspect and with the surrounding context, resulting in modifications in the temporal structure as well as in the spatial dimension and particularly the viewpoint. The special representation of events created by the narrative imperfect is more easily transmittable to Estonian in case of a weak contrast. On the other hand, translation problems increase in the presence of a sharp contrast.

Keywords: discourse analysis, text analysis, narratology, tense, aspect, Estonian, Spanish 